\title{
Impact of pretreatment on the landfill behaviour of MBT waste
}

\author{
A. A. Siddiqui ${ }^{1}$, W. Powrie $^{2}$ \& D. J. Richards ${ }^{2}$ \\ ${ }^{1}$ Department of Civil Engineering, Aligarh Muslim University, India \\ ${ }^{2}$ Waste Management Research Group, University of Southampton, UK
}

\begin{abstract}
One of the main aims of the EU Landfill Directive is to reduce significantly the landfilling of biodegradable municipal waste. Mechanical-biological pretreatment of municipal solid waste has become popular and is often adopted to enable compliance with this requirement of the Landfill Directive. This will have major implications for the nature of the waste that is disposed of to landfills and hence for the way in which the landfills should be managed. Pretreatment will cause changes in the composition and properties of the waste going to landfills including the gas generating potential, leaching behaviour and settlement characteristics. Germany has set strict allocation criteria for landfilling of mechanically biologically treated (MBT) waste. In contrast, there are no standards for MBT waste in the UK. Experimental studies were conducted to investigate the biodegradation and settlement behaviour of MBT waste samples treated to typical UK and German standards. The performance of large scale consolidating anaerobic reactors was monitored in terms of gas generating potential, leaching behaviour and waste settlement. The contributions of mechanical creep and biodegradation to secondary settlement were also identified.
\end{abstract}

Keywords: landfill, pretreated waste, leachate, biogas, waste settlement.

\section{Introduction}

Landfill has been the dominant municipal solid waste (MSW) management option for disposal of residual waste in the UK and many other countries for over a century. The EU Landfill Directive (EC [1]) sets targets for all Member States to reduce substantially the amount of biodegradable MSW going to landfill. 
Many European countries (e.g. Germany, Austria) required to comply with the Directive earlier than the UK have chosen mechanical-biological pretreatment (MBP) as a technology for treating MSW to arrive at the targets set out in the Landfill Directive. MBP normally involves sorting to remove recyclables and, in some cases, combustible materials; particle size reduction (e.g. shredding and screening) and partial biodegradation by anaerobic digestion and/or aerobic composting processes. MBP facilities have been commissioned over recent years and its role in waste management is expected to become more popular in near future.

In Germany, waste pretreatment processes are more advanced and a Landfill Ordinance (German EPA [2]) has set very strict allocation criteria for the landfilling of MBT waste. In contrast, the UK has not defined standards for landfilled MBT waste and a quantitative approach is employed to reduce the amount of biodegradable municipal waste (BMW) which is landfilled in accordance with the Landfill Directive. Pretreatment will have major implications on the degradation and settlement characteristics of the waste in landfills. The long term behaviour of MBT waste will be different from that of unprocessed MSW since the pretreatment process may change its physical, chemical and biological properties. Biogas and leachate characteristics of pretreated waste based on small scale studies have been reported by a few authors (e.g. Bayard et al. [3]; Bockreis and Steinberg [4]; Horing et al. [5]; Leikam and Stegmann [6]). These studies demonstrate that MBT waste has reduced gas generating potential and leachate strength. None of the studies on MBT waste to date have included consideration of the settlement characteristics, and therefore uncertainties remain about the creep and biodegradation induced settlements.

This study represents experimental results for the long term biodegradation and settlement behaviour of the two specimens of MBT waste, treated to typical UK and German standards.

\section{Waste samples}

Two different waste materials were studied: UK MBT and German MBT. They originate from two different MBP plants, one in the UK and one in Germany.

\subsection{MBT waste from Southern England (UK MBT waste)}

A sample of about $500 \mathrm{~kg}$ of MBT waste was obtained from White's Pit waste processing plant, a mechanical-biological treatment facility in Southern England. This facility includes a shredder, conveyor belts, magnets, screens and windrows for aerobic composting. The waste was first sorted to extract recyclable material and then broken down into smaller parts by shredding and screened followed by recovery of ferrous metals. Waste was then aerobically composted in forced aerated windrows in fully enclosed halls for about six weeks. The material was screened again to extract any remaining dry recyclables, giving a maximum particle size for the waste of about $20 \mathrm{~mm}$. 


\subsection{MBT waste from Northern Germany (German MBT waste)}

A sample of about $120 \mathrm{~kg}$ of MBT waste was obtained from Hannover Waste Treatment Centre, a mechanical-biological treatment facility in Hannover, Northern Germany. The waste was sorted, shredded and screened, and recyclable materials and metals were removed. The high calorific value fraction (mainly non-recycled paper and plastics) was sent as a refuse derived fuel to the incineration plant. Waste was then anaerobically digested in fermentation tanks for a period of 3 weeks. The digested material was composted in enclosed windrows for about 6 weeks. The maximum particle size of the residual material was about $60 \mathrm{~mm}$.

\section{Waste characterisation}

\subsection{Particle size distribution}

Representative samples of about $25 \mathrm{~kg}$ of both the UK and the German MBT waste were prepared by quartering the bulk sample. These samples were then sieved mechanically through a set of sieves into different fractions. The particle size distribution for both MBT samples is given in fig. 1. There were no significant differences between the results for the two wastes except that the German MBT waste had a higher fraction of large size particles and slightly less fine material than the UK MBT waste.

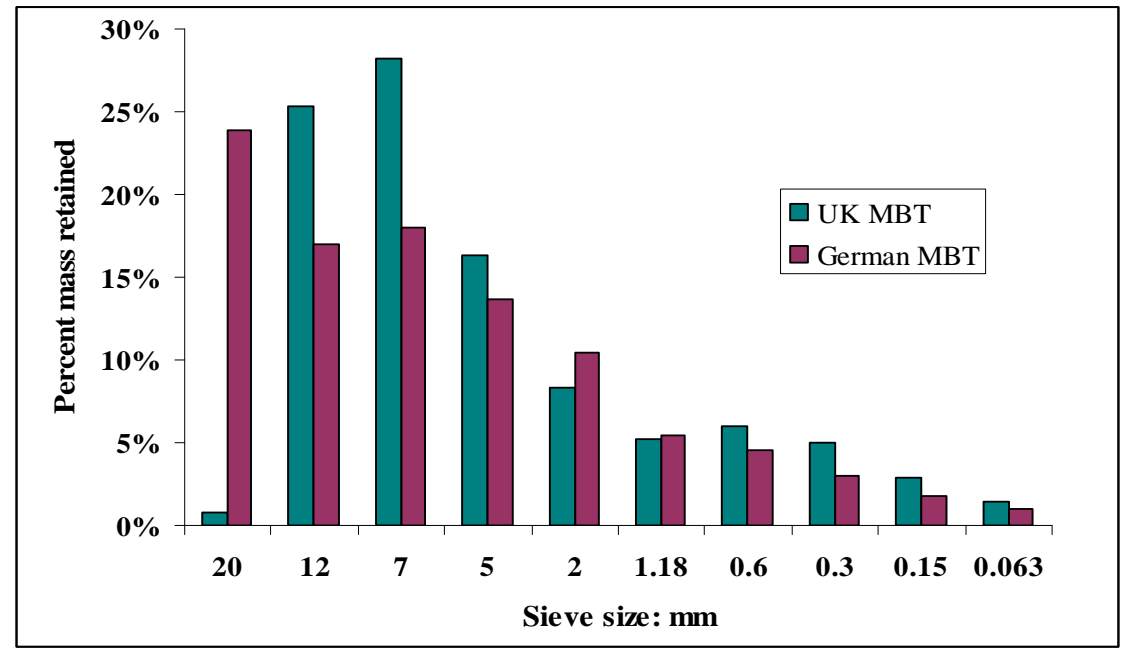

Figure 1: $\quad$ Particle size distribution of UK and German MBT waste.

\subsection{Waste composition}

Each size fraction (except that less than $5 \mathrm{~mm}$ ) from each MBT waste was sorted manually into various material categories i.e. flexible plastics, rigid plastics, 
textiles, paper, glass, wood, bones, rubber, ceramics, metals, stones and unidentified $>5 \mathrm{~mm}$. All material $<5 \mathrm{~mm}$ was placed in the "unidentified $<5 \mathrm{~mm}$ " category. The "unidentified" category represents a mixture of different components that could not be identified or further separated. The unidentified $>5$ $\mathrm{mm}$ category consists of particles greater than $5 \mathrm{~mm}$ whose material could not be identified, usually because they were encased in soil-like material which was impossible to remove without breaking the particle. The composition of each waste sample by material type (expressed as percentage of the total dry weight) is given in table 1. Owing to different processing of waste in the pretreatment stages, UK MBT waste is slightly different from the German MBT waste.

Table 1: $\quad$ MBT waste components expressed as dry weight percentages.

\begin{tabular}{|c|c|c|}
\hline \multirow{2}{*}{ Component } & \multicolumn{2}{|c|}{ Percentage of dry mass (\%) } \\
\cline { 2 - 3 } & UK MBT waste & German MBT waste \\
\hline Paper & 0.43 & 0.18 \\
\hline Flexible Plastics & 4.57 & 2.4 \\
\hline Rigid Plastics & 6.27 & 5.91 \\
\hline Wood & 1.57 & 3.22 \\
\hline Textile & 1.33 & 0.63 \\
\hline Rubber & 0.18 & 0.25 \\
\hline Bones & 0.27 & 0.37 \\
\hline Metal & 0.49 & 1.49 \\
\hline Ceramics & 2.29 & 4.25 \\
\hline Stones & 1.73 & 3.17 \\
\hline Glass & 22.77 & 24.36 \\
\hline Unidentified $>5 \mathrm{~mm}$ & 28.95 & 26.75 \\
\hline Unidentified $<5 \mathrm{~mm}$ & 29.15 & 27.02 \\
\hline Total & 100.00 & 100.00 \\
\hline
\end{tabular}

\section{Equipment}

Large scale consolidating anaerobic reactors were set up in the laboratory to simulate anaerobic conditions in a landfill. The consolidating anaerobic reactor (CAR) comprises a Perspex cylinder $480 \mathrm{~mm}$ diameter, $900 \mathrm{~mm}$ tall, and a load delivery system that can apply a constant vertical stress to the waste. A $10 \mathrm{~cm}$ gravel drainage layer was placed at the base of the CAR followed by a geotextile membrane. The MBT waste (which had been dried in an oven at $70^{\circ} \mathrm{C}$ ) was placed in the CAR in 10 successive layers of $4 \mathrm{~kg}$ each compacted to a thickness of $5 \mathrm{~cm}$ by hand tamping. A further layer of gravel (5 $\mathrm{cm}$ thick) was placed to give an even distribution of leachate over the top surface of the waste, and was again separated from the waste by a geotextile membrane. The CAR was placed within a compression loading rig, and the leachate was recirculated from the bottom to the top using a peristaltic pump. Biogas production was determined by allowing the gas to build up in the headspace volume to a small positive pressure 
above ambient atmospheric pressure measured by a pressure sensor. The details of CAR and gas measurement are given in Siddiqui et al. [7].

\subsection{CAR start up and operation}

Long term testing of each MBT waste was undertaken using two CARs: a control reactor (CAR1) and a test reactor (CAR2) (see fig. 2). Synthetic leachate containing mineral nutrients and trace elements dissolved in deionised water as described by Florencio et al. [8] was used in this study. CAR2 was filled with 80 litres of leachate comprising an inoculum of anaerobically digested sewage sludge (10\% vol.) derived from an anaerobic digester. This was done to ensure the presence of viable methanogenic bacteria and to accelerate the initiation of methanogenesis. In the control reactor (CAR1), 80 litres of leachate mixed with acetic and propionic acids at a concentration of 10 grams per litre each was added to suppress microbial activity and prevent the onset of methanogenesis. The reactors were then sparged with nitrogen gas to remove any oxygen trapped within the reactor and the leachate was recirculated continuously from the bottom to the top of each reactor. CAR1 was operated at $\sim 20^{\circ} \mathrm{C}$ in a controlled temperature room and CAR2 was maintained at a constant mesophilic temperature of $30^{\circ} \mathrm{C}$ using a heat blanket to establish a favourable growth environment for the microorganisms in the reactor.

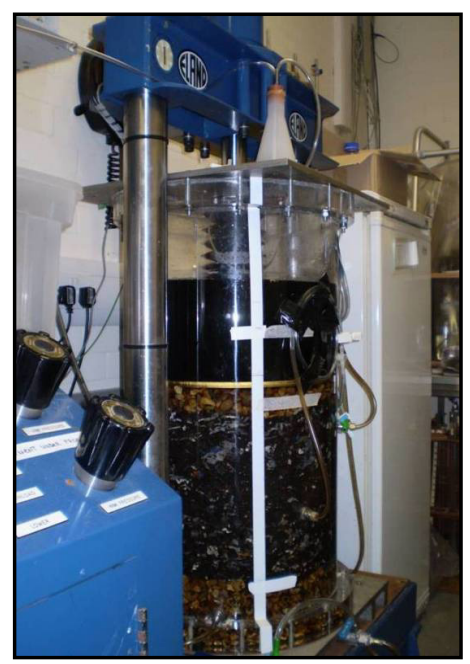

(a)

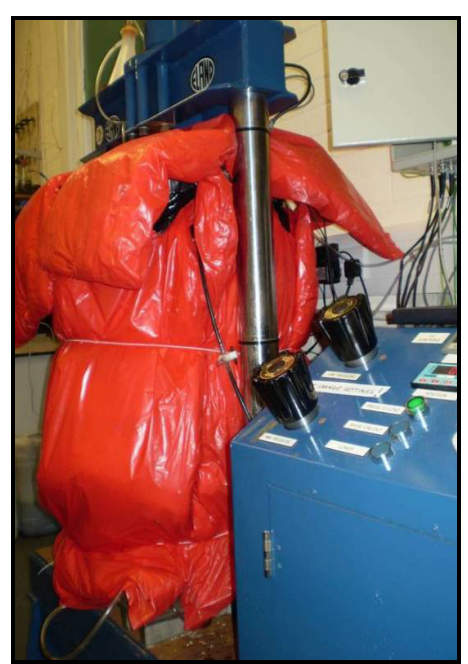

(b)

Figure 2: $\quad$ Consolidating anaerobic reactors (a) CAR1 (b) CAR2.

The operation of the CARs in this way was designed to isolate settlements due to mechanical creep from those due to biodegradation, by comparing the settlements measured in each. The CARs were operated for 347 and 279 days for the UK MBT and German MBT waste respectively. The load was maintained at $50 \mathrm{kPa}$ for the first 286 and 202 days of the experiment on the UK and German 
MBT waste respectively. Thereafter, load was increased to $150 \mathrm{kPa}$ for the remainder of the test in order to investigate any dependence of the creep characteristics of the waste on the applied load.

\subsection{Monitoring and testing programme}

Biogas volume and composition, leachate characteristics and waste settlement were monitored on a regular basis to understand the degree of waste stabilisation. The volume of biogas produced was recorded daily and analysed for gas composition. Leachate samples were collected and analysed every three days during the first three months of operation and weekly thereafter. Waste settlement was monitored daily using a linear variable displacement transducer.

\section{Analytical procedures}

The biogas composition (methane and carbon dioxide) in the CARs was measured daily as a percentage by volume using an infra-red gas analyser GASCARD II Plus. The biogas composition was not analysed in duplicate. Total organic carbon (TOC) and ammoniacal nitrogen $\left(\mathrm{NH}_{4}-\mathrm{N}\right)$ analyses of leachate were carried out using a high temperature Dohrmann-Rosemount DC 190 TOC analyser and Foss Tecator Kjeltec System 1002 distillation unit respectively. Leachate samples taken from the reactors were analysed in duplicate and the results presented are the average of these measurements.

\section{Results and discussion}

\subsection{Biogas generating potential}

The cumulative gas production for the UK and German MBT waste is illustrated in fig. 3. The gas production started soon after filling the test reactor, CAR2, for both the UK and German MBT waste. Biogas production was relatively low during the first week of operation, presumably due to the time taken for the acclimatisation of the methanogenic bacteria and the accumulation of VFA which kept the $\mathrm{pH}$ low. The biogas production then increased and methanogenic conditions were quickly established as confirmed by the change in biogas composition to about $60 \% \mathrm{CH}_{4}$ and $35 \% \mathrm{CO}_{2}$ by volume. The acidogenic phase was virtually absent; probably due to the degradation of some organic compounds during pretreatment. This is in agreement with the findings of Bayard et al. [3] and Bockreis et al. [9]. Biogas production continued at a much lower rate until day 280 and 195 when it had effectively ceased for the two wastes respectively. The gassing potential of the German MBT waste was low compared with the UK MBT waste. The total biogas yield was $49.46 \mathrm{~L} / \mathrm{kg} \mathrm{DM}$ (litres per kilogram dry matter) and $17.74 \mathrm{~L} / \mathrm{kg}$ DM for the UK and German MBT waste respectively. The control reactor, CAR1, for the UK and German MBT waste did not produce biogas due to the acidification of the reactor with acetic and propionic acids at the start of the experiment. 


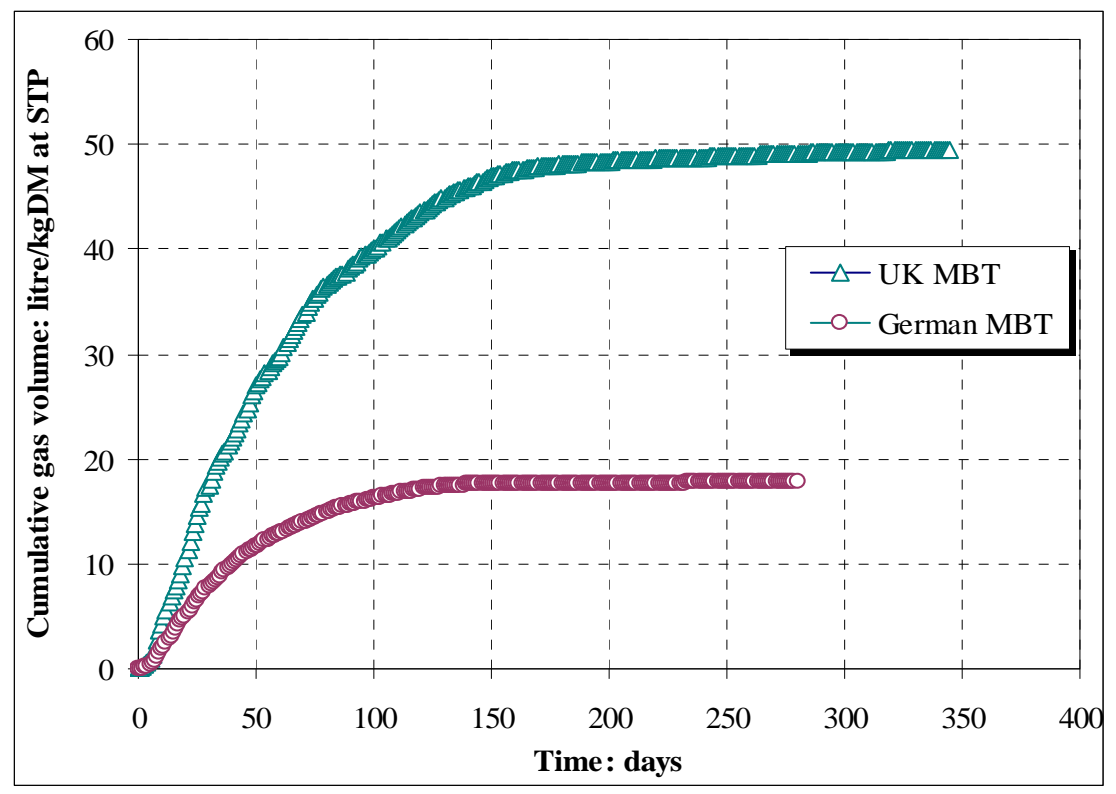

Figure 3: Cumulative biogas production in CAR2.

\subsection{Leachate quality}

The total organic carbon in the leachate was analysed and the results for CAR2 for the UK and German MBT waste are presented in fig. 4. The TOC concentration increased during the first week due to the hydrolysis of organics from the waste into the leachate at the initial stage. After the first week, the TOC concentration began to decrease slowly with the progression of stabilisation processes and confirmed by the increase in gas production and the high methane content of the biogas. Towards the end of the study TOC concentrations were about 650 and $290 \mathrm{mg} / \mathrm{L}$ for the UK and German MBT waste respectively. This TOC is mostly recalcitrant or hardly biodegradable carbon present in the reactor as suggested by Kjeldsen et al. [10]. The organic strength i.e. TOC of the leachate from the German MBT waste was low compared with that from the UK MBT waste, owing to the different biological processing steps during pretreatment. The German MBT waste was produced after a longer duration (about 9 weeks) of anaerobic and aerobic biological treatment of raw MSW compared with 6 weeks of aerobic biological treatment for the UK MBT waste.

The concentration of ammoniacal nitrogen $\left(\mathrm{NH}_{4}-\mathrm{N}\right)$ in the leachate from CAR2 for the UK and German MBT waste is shown in fig.5. The initial sharp increase in $\mathrm{NH}_{4}-\mathrm{N}$ is the result of direct leaching of ammonia from the waste, and the microbial degradation of nitrogenous organics (Berge et al. [11]; Jokela and Rintala [12]). After an initial increase, ammoniacal nitrogen concentration decreased very slowly to a stable concentration of about $425 \mathrm{mg} / \mathrm{L}$ and $195 \mathrm{mg} / \mathrm{L}$ for the UK and German MBT waste respectively. The results indicated that the 


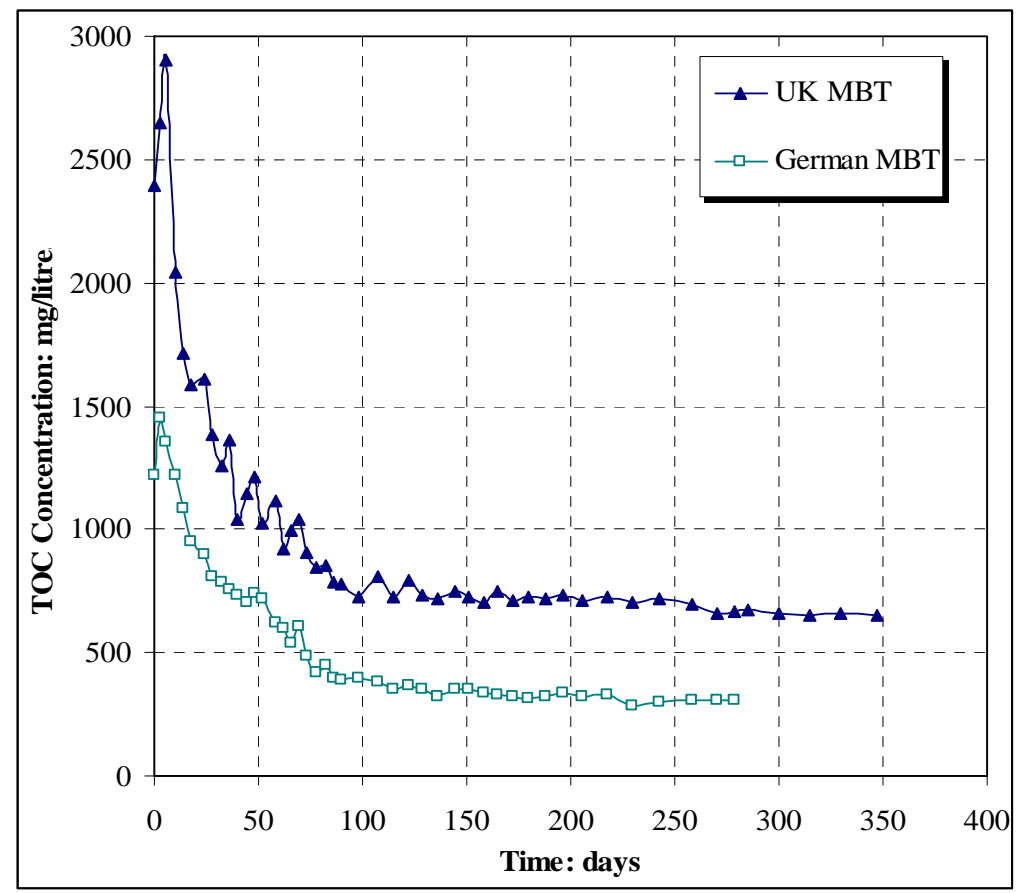

Figure 4: $\quad$ Leachate TOC in CAR2 for the UK and German MBT waste.

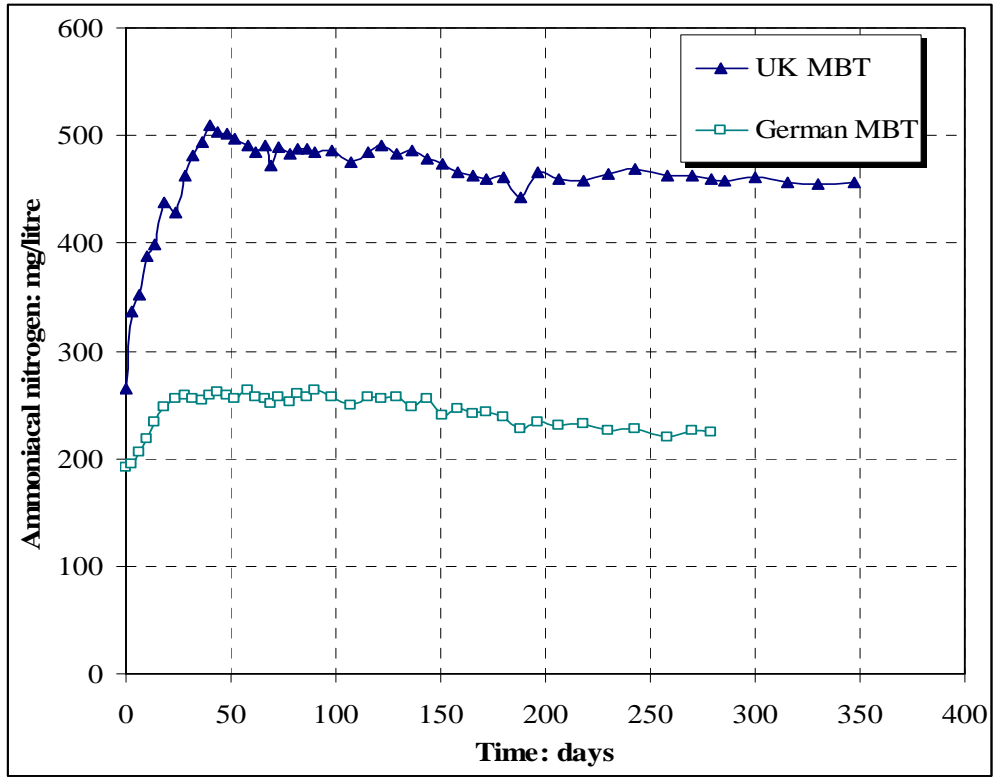

Figure 5: $\quad$ Leachate ammoniacal nitrogen in CAR2. 
nitrogen content in the leachate from the German MBT waste was less than that from the UK MBT waste.

\subsection{Waste settlement}

The CARs were operated at $50 \mathrm{kPa}$ load until day 286 for the UK MBT waste, and until day 202 for the German MBT waste. The load was then increased to $150 \mathrm{kPa}$ for the remainder of the tests to investigate any dependence of the creep characteristics of the waste on the applied load.

The majority of the settlement occurred immediately in response to the application of the load which may be due to lack of compaction of the waste during emplacement of waste in CARs. The primary settlement by the end of 24 hours resulted in additional settlements in the range $5.9 \%$ to $7.8 \%$ after immediate settlement for the UK and German MBT waste.

The secondary settlements measured in the CARs at $50 \mathrm{kPa}$ for the UK and German MBT waste are plotted against log-time in figs. 6 and 7 respectively. With data collected from both test and control reactors, it was possible to compare and quantify the net effects of creep and biodegradation on settlement. The total secondary settlement was $5.09 \%$ in CAR1 and $8.26 \%$ in CAR2 for the UK MBT waste, and $4.09 \%$ in CAR1 and 5.75\% in CAR2 for the German MBT waste. The rate and magnitude of secondary settlement in CAR2 were higher than CAR1 (shown by the steeper slopes in figs. 6 and 7) for both the UK and German MBT waste due to the decomposition of organics, evidenced by the increase in biogas production and decrease in TOC.

For both waste, CAR1 remained biologically inhibited over the entire duration of the tests and as a result, settlement may be considered to be due to mechanical creep only. The settlement of the UK and German MBT waste in CAR2 can be attributed to both mechanical creep and biodegradation. Settlements due to mechanical creep can be isolated from those due to biodegradation, by comparing the settlements measured in each assuming that creep effects were the same in both CARs. Secondary settlement associated with mechanical creep was $5.09 \%$ and $4.09 \%$ and that associated with biodegradation was $3.17 \%$ and $1.66 \%$ for the UK and German MBT waste respectively.

\section{Conclusions}

The gas generation potential, leachate quality and settlements have demonstrated that waste stabilisation was achieved in less than a year under enhanced biodegradation conditions in the CARs for the UK and German MBT waste. The total volume of biogas produced at STP for the UK and German MBT waste was $49.46 \mathrm{~L} / \mathrm{kg} \mathrm{DM}$ and $17.74 \mathrm{~L} / \mathrm{kg} \mathrm{DM}$ respectively. The higher gassing potential of the UK MBT waste could be explained by the lower degree of biological pretreatment.

The organic strength of the leachate from the German MBT waste was low compared with that from the UK MBT waste owing to the different biological processing steps during the pre-treatment. The leachate load of ammoniacal 


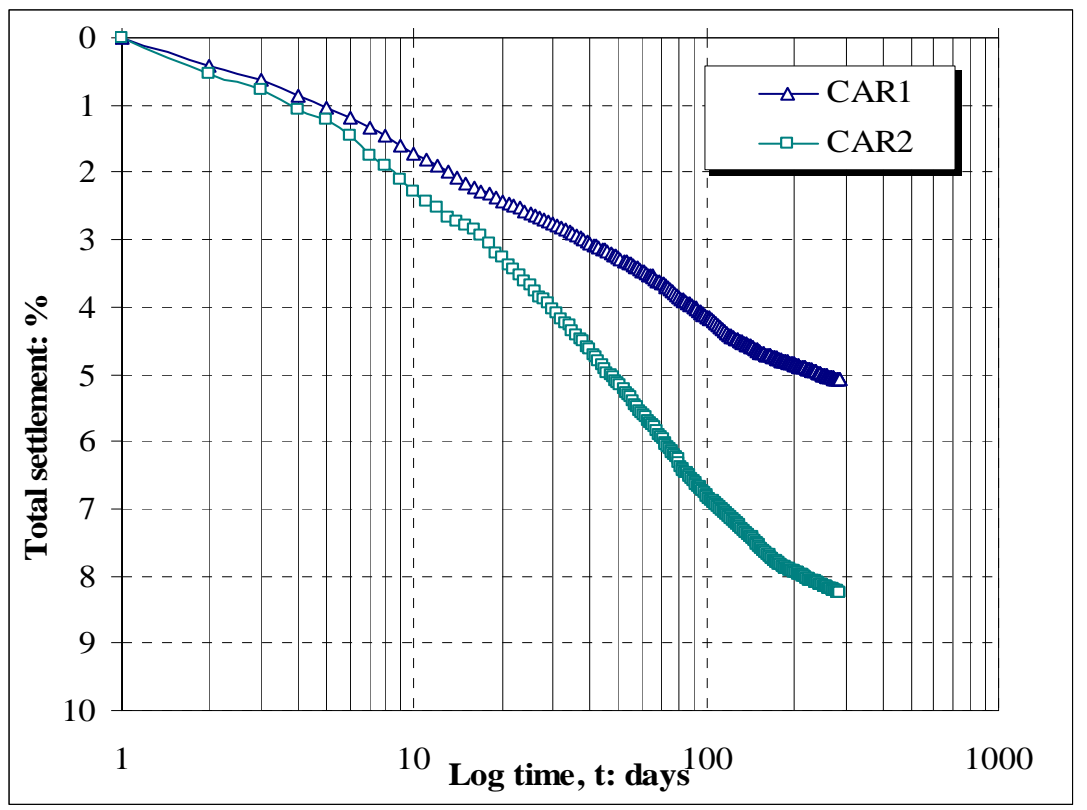

Figure 6: $\quad$ Secondary settlement in CARs at $50 \mathrm{kPa}$ for the UK MBT waste.

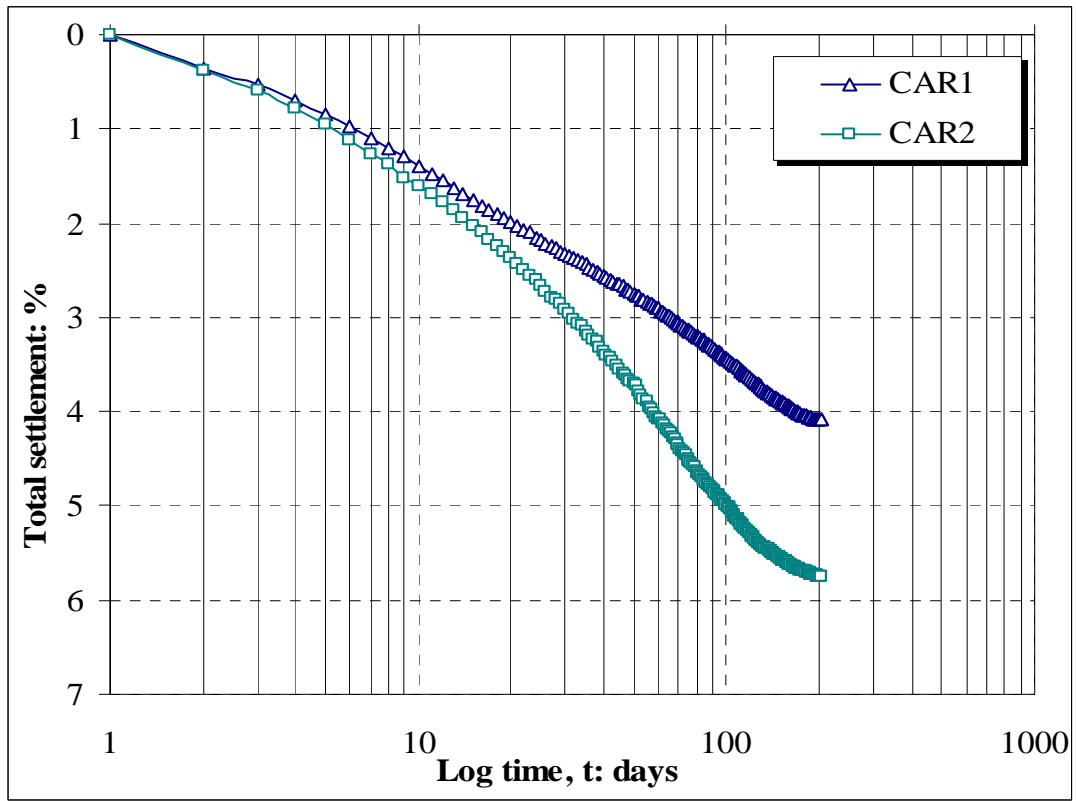

Figure 7: Secondary settlement in CARs at $50 \mathrm{kPa}$ for the German MBT waste. 
nitrogen from the German MBT waste was less than that from the UK MBT waste which was probably due to the lower nitrogen content of the German MBT waste.

Secondary settlement due to mechanical creep was more significant than that due to biodegradation, highlighting the importance of mechanical creep on the overall magnitude of secondary settlement.

\section{References}

[1] European Commission Directive 1999/31/EC on the Landfill of Waste. Council of the European Union, Official Journal of the European Communities, L182, pp. 1-19, 1999.

[2] German EPA. 2001. Ordinance on Environmentally Compatible Storage of Waste from Human Settlements and on Biological Waste Treatment Facilities (AbfAblV). Federal Ministry for the Environment, Nature Conservation and Nuclear Safety, Berlin, Germany, 2001. www.bmu.de/english/waste_management/downloads/doc/3371.php

[3] Bayard R., de Araujo Morais, J., Rouez, Fifi M U., Achour, F. and Ducom, G., Effect of biological pretreatment of coarse MSW on landfill behaviour: laboratory study, Water Science and Technology, 58.7, pp. 1361-1369, 2008.

[4] Bockreis, A. and Steinberg, I., Influence of mechanical-biological waste pre-treatment methods on the gas formation in landfills. Waste Management 25, pp. 337-343, 2005.

[5] Horing, K., Kruempelbeck, I. and Ehrig, H.J., Long term emissions behaviour of mechanical-biological pretreated municipal solid waste. In: T. H. Christensen, R. Cossu and R. Stegmann (Eds.) Proceedings Sardinia 1999, Seventh International Waste Management and Landfill Symposium, S. Margherita di Pula, Cagliari, Italy, 1999.

[6] Leikam, K., and Stegmann, R., Influence of mechanical-biological treatment of municipal solid waste on landfill behaviour. Waste Management and Research 17, pp. 424-429, 1999.

[7] Siddiqui A. A., Richards D. J., and Powrie W., A preliminary analysis of mechanically biologically treated waste: biodegradation and settlement behaviour. Proc. of the twelfth International Waste Management and Landfill Symposium, S. Margherita di Pula, Cagliari, Italy, 2009.

[8] Florencio, L., Field, J. A., and Lettinga, G., Substrate competition between methanogens and acetogens during the degradation of methanol in UASB reactors. Water Research 29(3), pp. 915-922, 1995.

[9] Bockreis, A., Steinberg, I., Rohde, C., and Jager, J., Gaseous emissions of mechanically-biologically pre-treated waste for long term experiments. Proc. of the Ninth International Waste Management and Landfill Symposium. S. Margherita di Pula, Cagliary, Italy. 2003.

[10] Kjeldsen, P., Barlaz, M.A., Rooker, R., Baun, A., Ledin, A., and Christensen, T. H., Present and long-term composition of MSW landfill 
leachate: a review. Critical Reviews in Environmental Science and Technology 32 (4), pp. 297-336, 2002.

[11] Berge, N.D., Reinhart, D.R., and Townsend, T.G., The fate of nitrogen in bioreactor landfills. Critical Reviews in Environmental Science and Technology, 35 (4), pp. 365-399, 2005.

[12] Jokela J.P.Y., and Rintala J.A., Anaerobic solubilisation of nitrogen from municipal solid waste. Reviews in Environmental Science and Biotechnology, 2, pp. 67-77, 2003. 